\title{
IDENTIFICATION OF SPRING BARLEY BREEDING LINES WITH SUPERIOR YIELD PERFORMANCE AND STABILITY
}

\author{
Volodymyr Hudzenko ${ }^{1}$, Tetiana Polishchuk¹, Oleksandr Demydov ${ }^{1}$, \\ Mykola Sardak², Nataliia Buniak², Vitalii Ishchenko ${ }^{3}$
}

\begin{abstract}
${ }^{1}$ Barley Breeding Laboratory, the V. M. Remeslo Myronivka Institute of Wheat (MIW) of the National Academy of Agrarian Sciences of Ukraine (NAAS), Tsentralne village, Myronivka district, Kyiv region, Ukraine

${ }^{2}$ Crop Breeding Laboratory, Nosivka Plant Breeding and Experimental Station of the V. M. Remeslo MIW of NAAS (NPBES), Doslidne village, Nosivka district, Chernihiv region, Ukraine

${ }^{3}$ Crop Breeding Department, Institute of Agriculture of Steppe of NAAS (IAS), Sozonivka village, Kirovohrad district, Kirovohrad region, Ukraine
\end{abstract}

Link to this article: https://doi.org/10.11118/actaun202068060947

Received: 15. 4. 2020, Accepted: 4. 12. 2020

To cite this article: HUDZENKO VOLODYMYR, POLISHCHUK TETIANA, DEMYDOV OLEKSANDR, SARDAK MYKOLA, BUNIAK NATALIIA, ISHCHENKO VITALII. 2020. Identification of Spring Barley Breeding Lines With Superior Yield Performance and Stability. Acta Universitatis Agriculturae et Silviculturae Mendelianae Brunensis, 68(6): 947-958.

\begin{abstract}
The aim of the present study was to substantiate theoretically and to test in practice scheme of multi-environment trials at the final stage of spring barley breeding process and to distinguish the genotypes which combine superior yield performance and stability. In the first year of competitive testing (2015) nine promising spring barley breeding lines have been selected under condition of the Central part of Forest-Steppe of Ukraine (latitude $49^{\circ} 64^{\prime}$, longitude $31^{\circ} 08^{\prime}$, altitude $153 \mathrm{~m}$ ). In 2016 and 2017, the genotypes were additionally tested in two other different agro-climatic zones of Ukraine: Polissia (latitude 50 $93^{\prime}$, longitude $31^{\circ} 69^{\prime}$, altitude $126 \mathrm{~m}$ ) and Northern Steppe (latitude $48^{\circ} 56^{\prime}$, longitude $32^{\circ} 32^{\prime}$, altitude $171 \mathrm{~m}$ ). In addition to the standard variety Vzirets, the breeding lines were compared with ten widespread spring barley varieties in agricultural production. Significant total yield variability of the genotypes and cross-over genotype by environment interaction has been revealed. It confirmed the validity of proposed combination of spatial (zones) and temporal (years) gradients for more efficient evaluation of the genotype by environment interaction and differentiation of genotypes in terms of yield performance and stability. As a practical result, using additive main effects and multiplicative interaction (AMMI) and genotype main effects plus genotype by environment interaction (GGE) models, four spring barley breeding lines with combination of superior yield performance and high stability have been identified.
\end{abstract}

Keywords: spring barley, yield, stability, genotype by environment interaction, AMMI, GGE biplot

\section{INTRODUCTION}

Barley (Hordeum vulgare L.) is one of the five major crops in world agriculture (Ullrich, 2011). Therefore, the augmentation of barley grain production as a result of increased productivity along with its stability is one of the priority breeding efforts. Grain yield, as the main integral economic characteristic of every commercial variety is formed depending on the influence of various different environmental factors. Genotypes differ in the efficiency of assimilation and conversion of environmental resources into the biomass of plant organs that form the phenotype (Malosetti et al., 2013). It has been shown that breeding genotypes 
for high-input and low-input environments should be carried out purposefully with selection and combination precisely those alleles and traits that contribute to yield formation under appropriate conditions (van Oosterom and Acevedo, 1992; Ceccarelli, 1996; von Korff et al., 2008; Pswarayi et al., 2008; Anbessa et al., 2010). It rarely happens that the ranges of vital factors of growing season conditions coincide with optimal for plants. At least one factor is limiting. Its effect on gene products (proteins-enzymes) leads to epigenetic regulation of genes and modifies phenotypic expression of quantitative traits. The presence of the epigenetic regulation of genes expression causes elementary adaptive reactions which are stages in the path of hereditary realization and are ultimately expressed in genotype quantitative and qualitative traits (Vasylkivskyi and Gudzenko, 2017). A genotype providing a relatively stable level of phenotypic expression of traits in different environments is characterized with wide adaptation. A genotype prevailing only in certain environment is specifically adapted. Specific adaptation is closely related to the genotype by environment interaction. This phenomenon is one of the central problems of plant breeding theory and practice (Hill, 1975; Zhao and $\mathrm{Xu}, 2012$; Malosetti et al., 2013). The commercial feature of modern plant breeding is the tight competition between breeding companies. It requires as fast as possible development of new varieties and introducing them in farming. Therefore, the assessment of breeding lines in the competitive testing should be in-depth, but not stretched in time. Multi-year trials in this aspect are not desirable, as they prolong the total period of the variety development. In contrast, testing genotypes in several environmental conditions (multi-environment trial) is effective for evaluation of genotype by environment interaction and selecting desirable ones (Sabaghnia et al., 2013; Mohammadi et al., 2014; Kendal and Doğan, 2015). The multi-environment trials allow conducting such comprehensive assessment in a shorter period of time. The first indisputable great success in testing breeding material under contrasting environments was achieved by Nobel Prize laureate N. Borlaug. In general, breeding success of major research centers shows that a significant role in their efficiency is related to the environmental conditions of their location. That is why not only genotype evaluation is important, but identification of testing location with optimal discriminating ability for selection of desirable genotypes also matters (Mirosavljević et al., 2018; Yan, 2019).

To interpret genotype by environmental experimental data from multi-environment trials, it is necessary to use the most appropriate statistical models. In general, in-depth analysis of genotype by environment interaction underlies the progress of any breeding program (van Eeuwijk et al., 2016).
Such analysis of genotype by environment data should include three major aspects: genotype evaluation, test-environment evaluation and megaenvironment analysis (Yan et al., 2007).

Thus, the aim of the present study was to substantiate theoretically and to test in practice scheme of multi-environment trials in the final stage of spring barley breeding process and to distinguish the superior genotypes which combine superior yield performance and stability. Accordingly to the mentioned above data, the experimental hypothesis of our research included several aspects: need for accelerate and comprehensive evaluation of spring barley breeding lines with the yield potential and its stability at the final stage of breeding process; determining the role of environmental conditions of the test and selection of location for successful breeding work; application of the most appropriate models for the comprehensive assessment of genotype by environmental experimental data.

\section{MATERIALS AND METHODS}

\section{Plant Material and Experimental Design}

Nine spring barley breeding lines have been selected in competitive testing at the V. M. Remeslo Myronivka Institute of Wheat (MIW) of NAAS in 2015. To evaluate the promising breeding lines more reliably, they were compared not only with standard variety Vzirets, but also with the varieties the most widespread in production conditions which were developed in different Ukrainian institutions: MIP Saliut and MIP Azart (MIW), Svaroh (Institute of Feed Research and Agriculture of Podillia of NAAS (IFRAP)), Statok and Krok (Institute of Agriculture of Steppe of NAAS) (IAS), Voievoda and Vsesvit (Plant Breeding and Genetics Institute - National Center of Seed and Cultivar Investigation of NAAS (PBGI)), Inkliuzyv and Perl (Plant Production Institute nd. a. V. Ya. Yuryev of NAAS (PPI)), as well as variety KWS Bambina developed at foreign company KWS LOCHOW GMBH, Bergen, Germany. The spring barley varieties were sown annually in the same block of competitive testing with the breeding lines. The most breeding lines were developed by means of individual selecting within hybrid populations resulted from crossing varieties bred at various Ukrainian institutions being adapted to the conditions of the region (Yukatan, Hetman, Darunok, Persei, Myronivskyi 92, and Vakula) and varieties from the West Europe (Sebastian, Barke, Belini, Philadelphia, Aspen, Symko and Annabell).

The choice of parental components of crosses allows combining in genotype high yield potential, malting quality, lodging and powdery mildew resistance from Western European varieties with adaptability to the conditions of Ukraine, drought tolerance, and leaf blotch resistance from native varieties. The only breeding line G7 has been selected within hybrid population resulted from 
I: Spring barley breeding lines/varieties

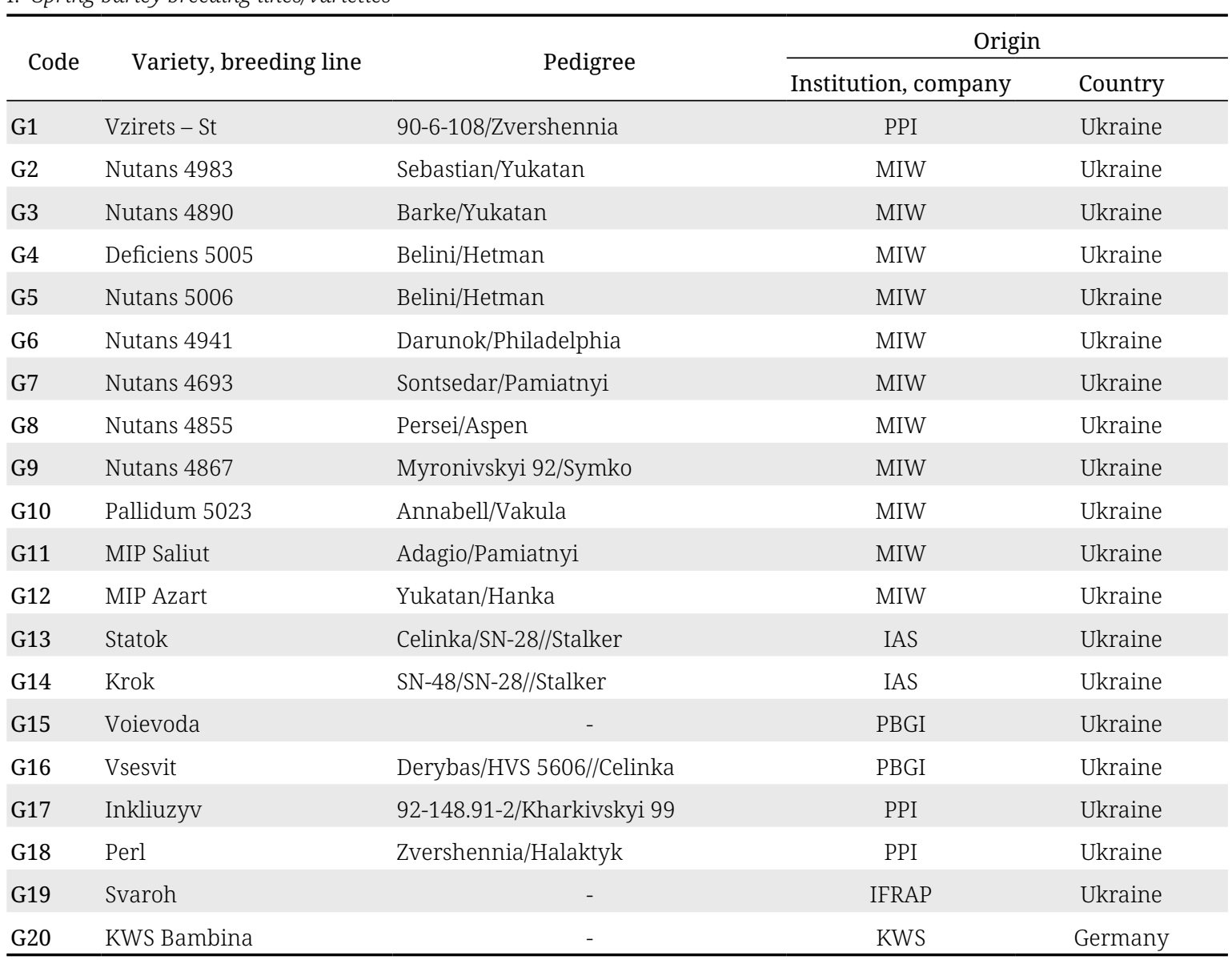

crossing two Myronivka varieties (Sontsedar and Pamiatnyi). It should also be noted that the breeding lines G4 and G5 have been selected within one hybrid combination (Belini/Hetman), but they belong to different botanical varieties - Deficiens and Nutans, respectively. The most genotypes studied are two-row barley form, except for the breeding line G10 being six-row one. The trial was laid out with randomized complete block design in three replications in each agro-climatic zone. The net plot size was $10 \mathrm{~m}^{2}$.

\section{Sites, Soils and Meteorological Conditions}

In 2016 and 2017, the trial was carried out in three locations which represented different agroclimatic zones: 1) Central part of the Forest-Steppe of Ukraine. Location is MIW (latitude - 4964', longitude $-31^{\circ} 08^{\prime}$, altitude $-153 \mathrm{~m}$ ). Soils are deep, little humus, slightly leached black. Humus content $3.8 \%$, alkaline hydrolyzed nitrogen $-5.9 \mathrm{mg} / 100 \mathrm{~g}$, $\mathrm{P}_{2} \mathrm{O}_{5}-22.1 \mathrm{mg} / 100 \mathrm{~g}, \mathrm{~K}_{2} \mathrm{O}-9.6 \mathrm{mg} / 100 \mathrm{~g}, \mathrm{pH}=5.8$. 2) Polissia of Ukraine. Location is Nosivka Plant Breeding and Experimental Station of the V. M. Remeslo MIW of NAAS (NPBES) (Distance from MIW is $240 \mathrm{~km}$ to the North, latitude - 5093',

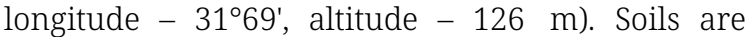
modal, little humus, leached black. Humus content
2.6\%, nitrogen $-8.5 \mathrm{mg} / 100 \mathrm{~g}, \mathrm{P}_{2} \mathrm{O}_{5}-12.2 \mathrm{mg} / 100 \mathrm{~g}$, $\mathrm{K}_{2} \mathrm{O}-7.5 \mathrm{mg} / 100 \mathrm{~g}, \mathrm{pH}=4.6$. 3) Northern Steppe of Ukraine. Location is IAS (Distance from MIW is $230 \mathrm{~km}$ to the South, latitude - 48 $56^{\prime}$, longitude $-32^{\circ} 32^{\prime}$, altitude $\left.-171 \mathrm{~m}\right)$. Soils are deep, middle humus, clay loamy black. Humus content 4.6\%, nitrogen - $12.0 \mathrm{mg} / 100 \mathrm{~g}, \mathrm{P}_{2} \mathrm{O}_{5}-11.6 \mathrm{mg} / 100 \mathrm{~g}, \mathrm{~K}_{2} \mathrm{O}$ $-11.8 \mathrm{mg} / 100 \mathrm{~g}, \mathrm{pH}=5.4$. Thus, for three years of competitive testing, the genotypes are evaluated in seven environments which consist of combination of contrasting agro-climatic zones and different years (3MIW + 2NPBES + 2IAS). Meteorological conditions during spring barley growing season significantly differed through agro-climatic zones and years (Tab. II).

\section{Statistical Analysis}

Additive main effects and multiplicative interaction (AMMI), as well as genotype main effects plus genotype by environment interaction (GGE) models were applied to evaluate genotype by environment interaction, test location characterisation, genotype differentiation, and to select breeding lines with combination of good yield performance and stability. Both AMMI and GGE models combine analysis of variance for additive parameters and singular value decomposition 
II: Meteorological conditions during spring barley growing season in three locations of Ukraine

\begin{tabular}{|c|c|c|c|c|c|c|c|c|c|}
\hline \multirow{2}{*}{ Year } & \multirow{2}{*}{ Code } & \multicolumn{4}{|c|}{ Monthly air temperature, ${ }^{\circ} \mathrm{C}$} & \multicolumn{4}{|c|}{ Monthly precipitation, mm } \\
\hline & & April & May & June & July & April & May & June & July \\
\hline \multicolumn{10}{|c|}{ The V. M. Remeslo Myronivka Institute of Wheat of NAAS (Central part of the Forest-Steppe) } \\
\hline 2015 & M15 & 9.3 & 16.3 & 19.4 & 21.5 & 34.0 & 55.0 & 101.0 & 99.0 \\
\hline 2016 & M16 & 12.4 & 15.2 & 20.1 & 22.2 & 55.4 & 91.7 & 68.6 & 19.1 \\
\hline 2017 & M17 & 10.4 & 15.4 & 20.6 & 21.0 & 42.7 & 23.6 & 20.1 & 101.8 \\
\hline Long-term & & 8.8 & 15.0 & 18.0 & 19.7 & 42.1 & 51.2 & 85.2 & 86.5 \\
\hline \multicolumn{10}{|c|}{ Nosivka Plant Breeding and Experimental Station of the V. M. Remeslo MIW of NAAS (Polissia) } \\
\hline 2016 & N16 & 11.7 & 15.3 & 20.0 & 21.8 & 58.4 & 122.9 & 36.5 & 51.3 \\
\hline 2017 & N17 & 9.5 & 13.9 & 18.6 & 19.1 & 35.4 & 44.3 & 33.0 & 109.3 \\
\hline Long-term & & 7.9 & 15.0 & 18.4 & 20.2 & 35.6 & 45.1 & 64.5 & 73.0 \\
\hline \multicolumn{10}{|c|}{ Institute of Agriculture of Steppe of NAAS (Nothern Steppe) } \\
\hline 2016 & K16 & 13.9 & 17.3 & 22.2 & 24.3 & 52.3 & 153.2 & 107.5 & 15.5 \\
\hline 2017 & K17 & 10.9 & 17.6 & 23.1 & 23.2 & 23.5 & 10.7 & 22.2 & 66.0 \\
\hline Long-term & & 8.9 & 15.3 & 18.6 & 20.0 & 36.0 & 45.0 & 66.0 & 72.0 \\
\hline
\end{tabular}

for multiplicative parameters, the principal components (Gauch et al., 2008). These results are graphically displayed as a biplot, first reported by Gabriel in 1971. The biplot is a scatter plot that approximates and graphically displays a two-way table by both its row and column factors so that relationships among the row factors, relationships among column factors, and the underlying interactions between the row and column factors can be visualized simultaneously. Mathematically, the biplot is regarded as a graphical display of matrix multiplication (Yan and Tinker, 2006; Hongyu et al., 2014). Comparisons AMMI and GGE biplot models, their similarities, peculiarities and advantages are discussed in several papers (Yan et al., 2007; Gauch et al., 2008). Graphical analysis was performed when using non-commercial software GEA-R Version 4.1. Software review is provided in the publication Frutos et al. (2014).

\section{RESULTS AND DISCUSSION}

\section{Grain Yield Performance of Spring Barley Genotypes}

Grain yield of spring barley genotypes varied, depending on agro-climatic zones and meteorological conditions of the year (Tab. III). Significant differences in genotypes yield performance were noted throughout all environments (zones plus years combinations). The maximal yield in environment M15 was observed for the breeding line G10 (8.35t/ha), in the M16 for the breeding line G4 (7.88t/ha), in M17 (5.42 t/ha) and N16 (7.07t/ha) for the breeding line G6, in the N17 for the breeding line G8 (7.15t/ha), in the K16 for the variety G13 (5.87t/ha), and in the K17 for the variety $\mathrm{G} 19$ (5.11t/ha). The highest mean yield was noticed in the breeding line G6 (6.39t/ha), the lowest mean yield had the variety G13 (5.32t/ha). Three breeding lines G6, $\mathrm{G} 8$, and $\mathrm{G} 4$ reliably ( $\mathrm{LSD}_{05}$ ) predominated in yield over the standard variety G1. Breeding lines G2, G3, as well as varieties G11, G12 had higher than standard variety yield, but within the error limits. Breeding lines G7, G9, G10, as well as varieties G17, G18, G19, and G20 were inferior than G1, but not reliably. Significantly poorer than standard in yield performance were breeding line G6 and varieties G13, G14, G15, G16.

Thus, there are identified significant changes of genotypes ranks in yield throughout environments which indicate the presence cross-over genotype by environment interaction. As it is known, there are different situations in which genotype by environment interactions occurs: divergence, convergence, and cross-over interaction. Among them, cross-over interaction is the most significant for breeders as it implies that the choice of the best genotype is determined by the environment (Malosetti et al., 2013). Several other researchers also reported about significant year to year, or site to site grain yield variation and cross-over genotype by environment interaction for spring barley genotypes (Mirosavljević et al., 2014; Pržulj et al., 2015; Solonechnyi et al., 2015).

\section{Genotype by Environment Interaction Evaluation}

Additive main effects and multiplicative interaction (AMMI) (Mehari et al., 2014; Abtew et al., 2015; Feriani et al., 2016; Verma et al., 2019; Bocianowski et al., 2019) and genotype main effects plus genotype by environment interaction (GGE biplot) (Meng et al., 2016; Bilgin et al., 2018; Oral 
III: Grain yield of spring barley breeding lines and varieties in the multi-environment trial, t/ha

\begin{tabular}{|c|c|c|c|c|c|c|c|c|c|}
\hline \multirow{4}{*}{ Code } & \multirow{4}{*}{ Variety, breeding line } & \multicolumn{7}{|c|}{ Environmental condition (site) and year of trial (code) } & \multirow{4}{*}{ Mean } \\
\hline & & \multicolumn{3}{|c|}{ MIW } & \multicolumn{2}{|c|}{ NPBES } & \multicolumn{2}{|c|}{ IAS } & \\
\hline & & 2015 & 2016 & 2017 & 2016 & 2017 & 2016 & 2017 & \\
\hline & & M15 & M16 & M17 & N16 & N17 & K16 & K17 & \\
\hline G1 & Vzirets - St & 7.02 & 6.88 & 4.66 & 6.01 & 6.61 & 5.73 & 4.53 & 5.92 \\
\hline G2 & Nutans 4983 & 7.32 & 6.32 & 4.56 & 6.70 & 7.06 & 5.67 & 4.73 & 6.05 \\
\hline G3 & Nutans 4890 & 7.35 & 7.59 & 5.27 & 6.01 & 6.38 & 5.21 & 4.32 & 6.02 \\
\hline G4 & Deficiens 5005 & 7.63 & 7.88 & 5.20 & 6.73 & 6.55 & 5.66 & 4.20 & 6.26 \\
\hline G5 & Nutans 5006 & 7.67 & 5.39 & 4.56 & 5.20 & 7.03 & 4.28 & 4.22 & 5.48 \\
\hline G6 & Nutans 4941 & 7.74 & 7.78 & 5.42 & 7.07 & 7.01 & 5.16 & 4.56 & 6.39 \\
\hline G7 & Nutans 4693 & 7.12 & 6.74 & 4.75 & 6.28 & 6.01 & 4.99 & 4.26 & 5.74 \\
\hline G8 & Nutans 4855 & 7.57 & 7.41 & 5.37 & 6.80 & 7.15 & 5.69 & 4.12 & 6.30 \\
\hline G9 & Nutans 4867 & 7.34 & 6.52 & 4.92 & 5.65 & 6.23 & 4.86 & 4.36 & 5.70 \\
\hline G10 & Pallidum 5023 & 8.35 & 6.34 & 4.25 & 5.85 & 6.87 & 5.59 & 3.71 & 5.85 \\
\hline G11 & MIP Saliut & 7.03 & 7.16 & 5.01 & 5.82 & 6.89 & 5.16 & 4.50 & 5.94 \\
\hline G12 & MIP Azart & 7.39 & 7.38 & 5.19 & 5.85 & 6.82 & 5.65 & 4.15 & 6.06 \\
\hline G13 & Statok & 6.44 & 4.79 & 4.22 & 5.46 & 6.30 & 5.87 & 4.14 & 5.32 \\
\hline G14 & Krok & 5.99 & 6.12 & 4.37 & 5.03 & 5.83 & 5.46 & 4.67 & 5.35 \\
\hline G15 & Voievoda & 6.58 & 5.32 & 4.83 & 6.28 & 6.34 & 5.80 & 3.50 & 5.52 \\
\hline G16 & Vsesvit & 6.32 & 4.55 & 4.59 & 6.05 & 6.20 & 5.38 & 4.38 & 5.35 \\
\hline G17 & Inkliuzyv & 7.07 & 5.71 & 4.50 & 5.82 & 6.43 & 5.43 & 4.83 & 5.69 \\
\hline G18 & Perl & 6.79 & 5.76 & 4.85 & 5.95 & 6.72 & 5.13 & 5.01 & 5.74 \\
\hline G19 & Svaroh & 6.68 & 5.72 & 4.76 & 6.01 & 6.67 & 4.94 & 5.11 & 5.70 \\
\hline G20 & KWS Bambina & 6.59 & 6.66 & 4.73 & 6.70 & 7.00 & 5.22 & 4.36 & 5.89 \\
\hline $\mathrm{LSD}_{05}$ & & 0.25 & 0.33 & 0.31 & 0.46 & 0.26 & 0.19 & 0.39 & 0.25 \\
\hline
\end{tabular}

et al., 2018; Al-Ghzawi et al., 2019; Al-Sayaydeh et al., 2019; Gudzenko, 2019) statistical tools have been the most widely used in recent years for evaluation of genotypes, test environments and interaction between them. Several researchers combined both of these graphical models for in-depth assessment of the experimental data from multi-environment trials (Doğan et al., 2016; Vaezi et al., 2017; Fana et al., 2018; Kendal et al., 2019).

Analysis of variance of the AMMI model showed a significant predomination the environmental conditions in the total variation (74.56\%) (Tab. IV). The genotype by environment interaction contribution was $17.21 \%$, and the genotype value was $8.23 \%$. Despite the last parameter had relatively low numerical value it was reliable. The low part of the genotype contribution to the total dispersion, in our opinion, is due to the fact that only the best breeding lines and varieties were involved in the experiment. Our data agree with many other literature sources (Ahmadi et al., 2012; Kendal and Doğan, 2015; Taheripourfard et al., 2017; Solonechnyi et al., 2018; Kendal et al.,
2019). However, other researchers point out the advantage of genotype-environment interaction (Dyulgerova and Dyulgerov, 2019). At the same time there are reports that the conditions of the year significantly exceeded and the lowest value was found for the genotype by environment interaction (Sabaghnia et al., 2013). Practically equal values of genotype and genotype by environment interaction were reported by Maniruzzaman et al. (2019) and Gudzenko (2019). Thus, the contribution of different factors to the total variation significantly depends on the studied genotypes and test conditions. It indicates the necessity of the testing every new set of genotypes in specific environments.

The first two principal components of the AMMI model (Factor 1, Factor 2) explained $66.47 \%$ of the genotype by environment interaction. AMMI1 biplot (Fig. 1) allows graphically analyzing the variance of genotypes and test environments and the interaction between them. The variation of the main additive effects (mean yield) of genotypes (G1...G20) and environments (M15...K17) is located on the horizontal axis (YLD). The first principal 
IV: Analysis of variance (AMMI model) of yield of the spring barley genotypes and sum of squares decomposition of the genotype by environment interaction

\begin{tabular}{lcccc}
\hline \multicolumn{1}{c}{ Source } & Sum of squares & Degrees of freedom & Mean square & Percentage relative to the sum of squares \\
\hline Genotype (G) & 39.56 & 19 & 2.08 & $8.23^{*}$ \\
Environment (E) & 358.48 & 6 & 59.75 & $74.56^{*}$ \\
G x E & 82.76 & 114 & 0.73 & $17.21^{*}$ \\
Factor 1 & 39.80 & 24 & 1.66 & $48.09^{*}$ \\
Factor 2 & 15.21 & 22 & 0.69 & $18.38^{*}$ \\
Factor 3 & 12.79 & 20 & 0.64 & $15.46^{*}$ \\
Factor 4 & 8.58 & 18 & 0.48 & $10.37^{*}$ \\
Factor 5 & 3.29 & 16 & 0.21 & 3.97 \\
Factor 6 & 3.08 & 14 & 0.22 & 3.72 \\
Factor 7 & 0.00 & 12 & 0.00 & 0.00 \\
Residuals & 10.03 & 280 & 0.04 & 0.00 \\
\hline
\end{tabular}

Factor $1 . . .7$ - principal components, ${ }^{*}$ - significant at $1 \%$ probability level

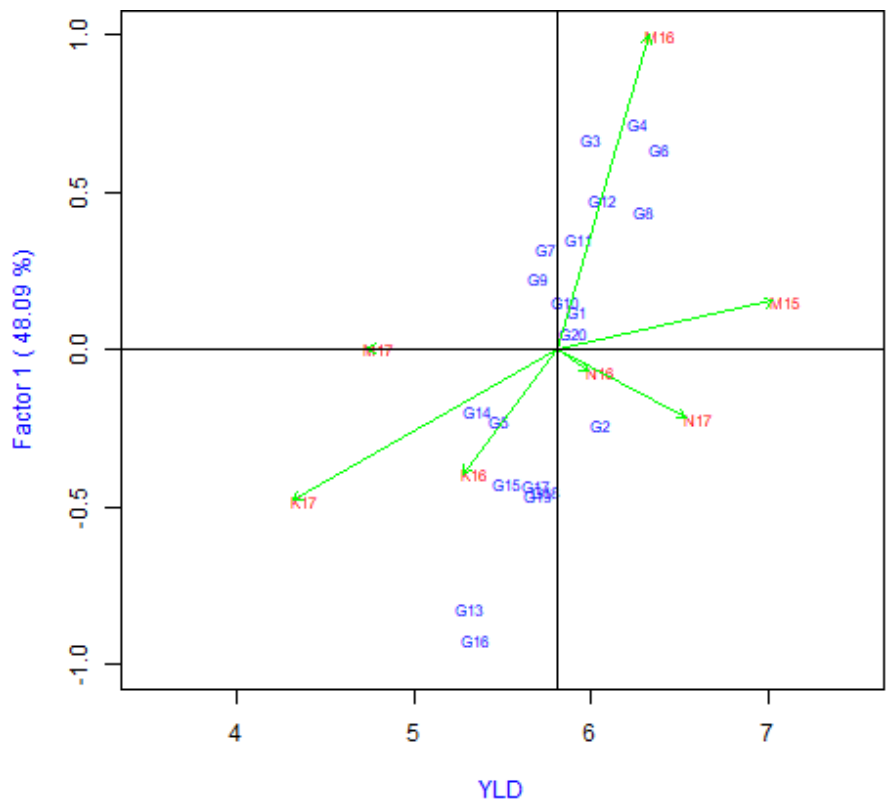

1: The AMMI1 biplot dispersion of spring barley genotypes and test environments in coordinates of mean yield (YLD) and the first principal component (Factor 1)

component of the multiplicative effects variation of the genotype by environment interaction is located on the vertical axis (Factor 1). The vertical line which passes through origin of the AMMI1 biplot represents the grand mean yield in the trial. The lines with the arrows at the end are the environment vectors. The vector length allows visualizing the remoteness the certain environment from the origin of the AMMI1 biplot along the mean yield axis or the axis of the principal component values. The AMMI2 biplot (Fig. 2) displays the multiplicative effects of genotype by environment interaction in the coordinates of the first (Factor 1) and the second (Factor 2) principal components. It is possible to visualize dispersion of the genotypes and environments in the principal component coordinates. Genotypes that are displaced from the origin of the AMMI2 biplot towards to the specific environment have a stronger positive reaction to its conditions.

It is evident, that the environment M16 had maximal distance from the biplot origin. The environment M15 was the most productive, and the environment K17 was the least productive. The genotypes G4, G3, G8, G6 and G12 combined the highest mean yield in the trial, but with a significant positive response to M16 conditions. The breeding line G2 had a combination of yield 


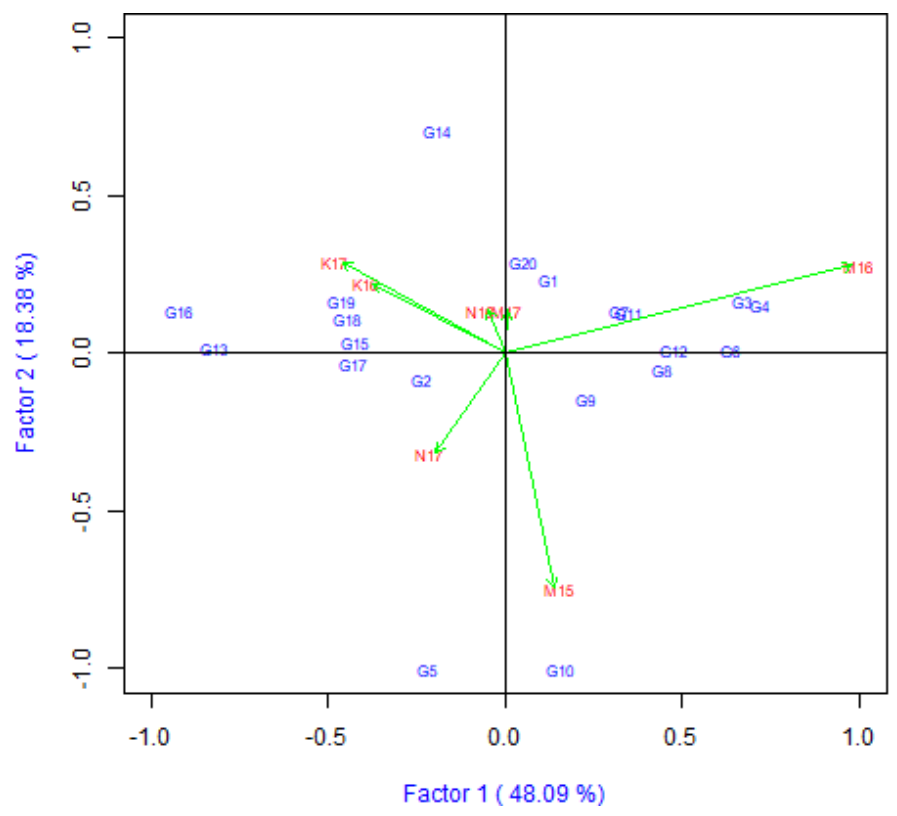

2: The AMMI2 biplot dispersion of spring barley genotypes and test environments in coordinates of the first two principal components

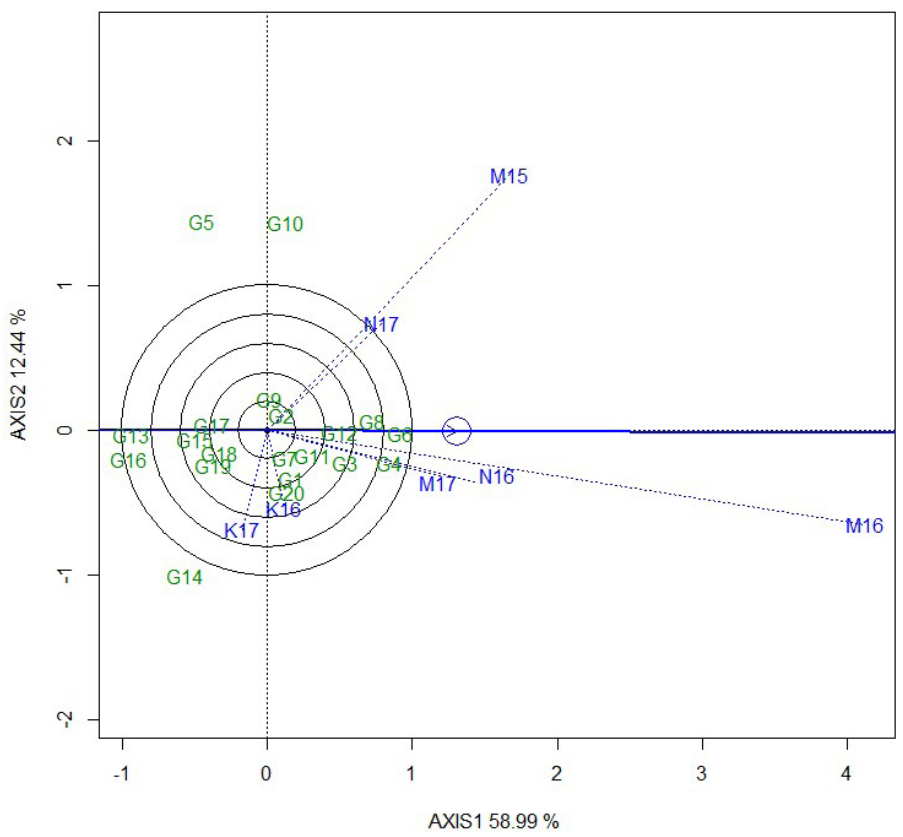

3: The GGE biplot of discriminating ability and representativeness of test environments

level and high positive reaction to the environment N17. The breeding line G10 had a strong specific adaptation to M15. The breeding line G5 positively responded to different years and environmental conditions (M15 and N17). Spring barley varieties G15, G17, G18, and G19 were more adaptable to environments K16 and K17.

Fig. 3 shows the representativeness and discriminating power of environments accordingly to the GGE biplot model. The first two principal components (Axis 1, Axis 2) explained $71.43 \%$ of the genotype by environment interaction. The line that intersects the biplot origin is the average environment axis (AEA). The average environment is represented on AEA with the small circle at the end of the arrow. The dashed lines indicate the vectors of individual test environments. The length of the vector characterizes discriminating power of an environment. The environment M16 had the longest vector, and accordingly, it was characterized by the highest discriminating power. The lowest discriminating power was 


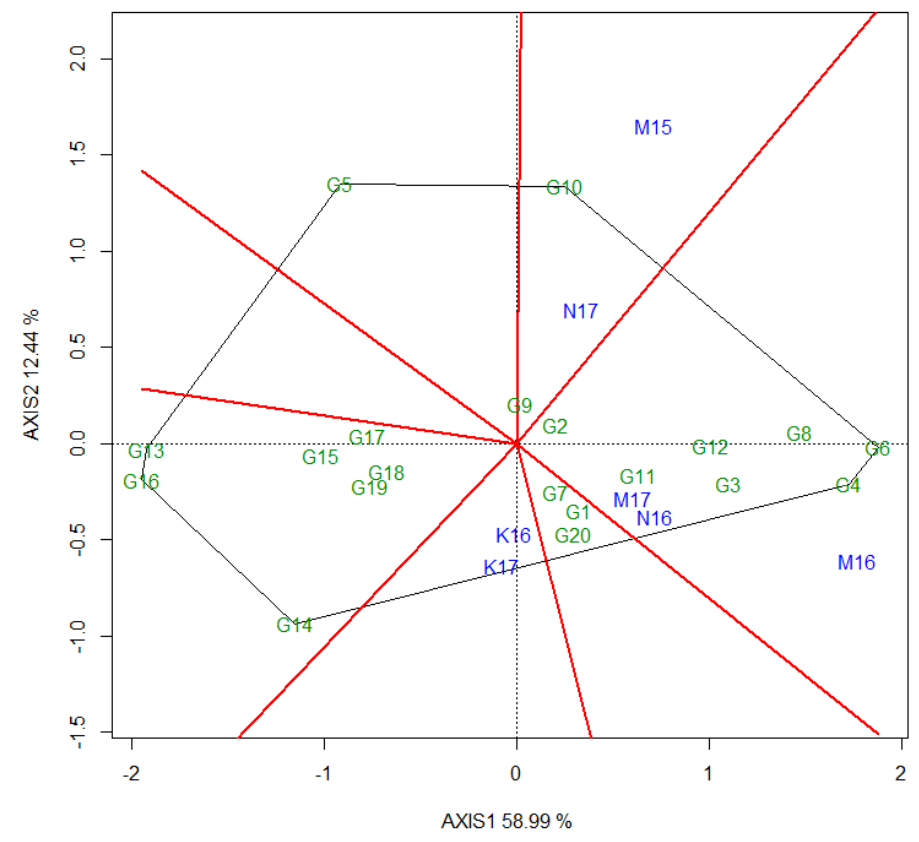

4: The GGE biplot "which-won-where" polygon view of spring barley genotypes and test environments

noted in the environments K16 and K17. The angle between an environment vector and the AEA showes its representativeness. A test environment that has smaller angle with AEA is more representative than other test environments. The highest representativeness was noted for the environment M16, and the lowest one was noted in K17. Thus, the M16 the most optimally combined differentiating power and representativeness, and K16 and K17 had the poorest their combination. The environments M15 and K17 were the most distant from each other, as it is evidenced by the largest angle between their vectors. The environments M17 and N16, as well as M15 and N17 were similar to each other, since they had the smallest angle between their vectors. However, it should be noted that the last two above mentioned environments significantly differed in discriminating power.

The GGE biplot “which-won-where” polygon view (Fig. 4) is effective option to visualize the interaction patterns between genotypes, environments and to conduct mega-environment analysis (Yan et al., 2007). The polygon is formed by connecting the genotypes that are farthest away from the origin of GGE biplot, such that all other genotypes are included within the polygon. A set of perpendicular to each side of the polygon lines divides the GGE biplot into several sectors. The sectors at the vertex of the polygon contain genotypes that have an advantage in a particular environment or in a set of environments (mega-environment). In our case, two sectors contained both environments and genotypes. Environments K16 and K17 were located in the sector with no genotypes. Thus, the environments are divided into different mega-environment which clearly confirmed about presence of cross-over genotype by environment interactions. The first mega-environment is formed with the environments M16, M17, and N16. The breeding lines G6 and G4 had advantage in it. The breeding lines G8, G3, G2, and varieties G12 and G13 are also located in the first mega-environment. The second mega-environment combines the conditions of M15 and N17. The breeding line G10 was the most adapted to this mega-environment. The standard variety G1, as well as the breeding lines G5, G7, and varieties G13, G14, G15, G16, G17, G18, G19, G20 had poorer performance as compared to the mentioned above genotypes and they were located in sectors that did not contain environments.

Summarizing the environments characteristics accordingly to GGE biplot model, it should be noted both the similarities between different agro-climatic conditions (M17 and N16, M15 and N17), as well as differences in the same agro-climatic conditions in different years (M15 and M17, N16 and N17). In addition, the considered environments had a different level of productivity. This indicates that not only mean productivity of the environments characterizes their similarity or difference in terms of discriminating power and representativeness, but also ranking the genotypes in yield performance. In other words, the mode of reaction of the studied genotypes significantly influenced on the statistical characteristics of the test environments. In general, it can be noted that the conditions of MIW (M15, M16, and M17) and NPBES (N16 and N17) were more favorable for the differentiation of this set of genotypes. The less favorable for differentiation of 


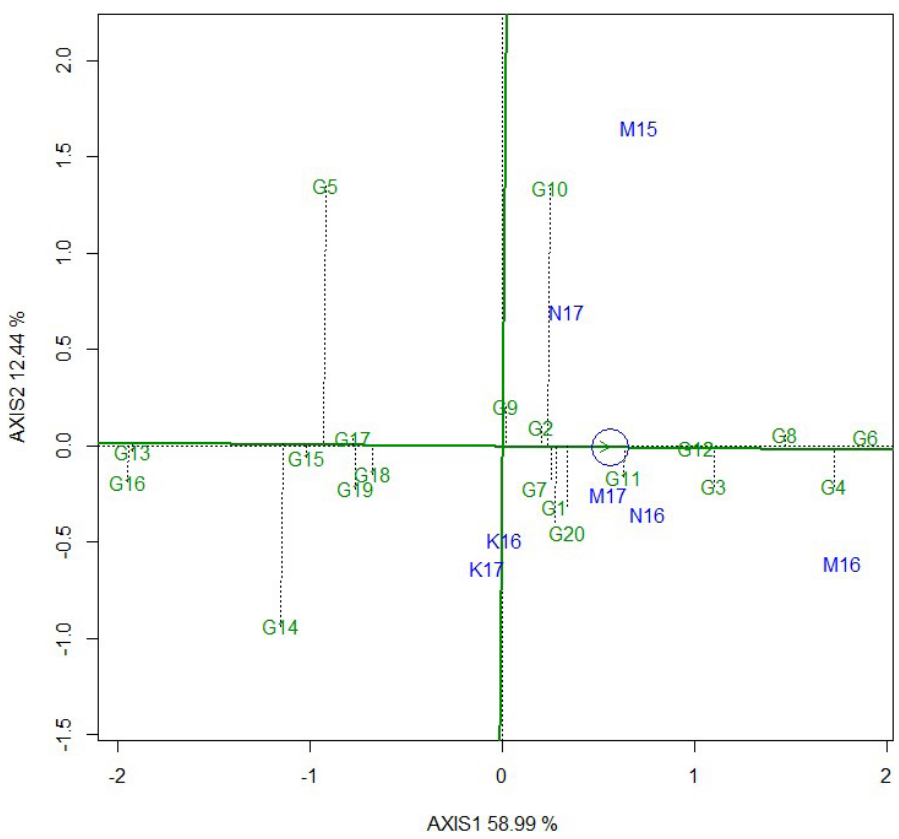

5: The GGE biplot average environment coordination view of mean yield against stability of spring barley genotypes

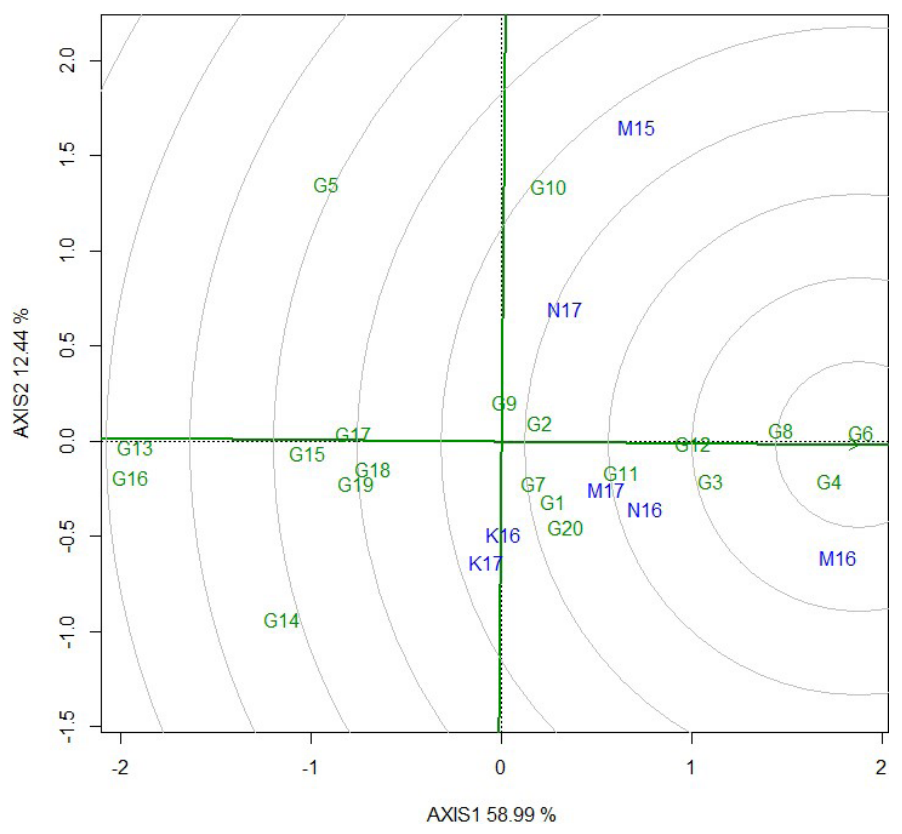

6: The GGE biplot ranking spring barley genotypes relative to an "ideal"

genotypes were conditions of IAS (K16 and K17). However, as will be shown below, testing of breeding lines in IAS was also important. The lines that have been highlighted in general trial were characterized by the best performance in MIW and NPBES, and did not "fail" in IAS conditions. In general, it should be mentioned the validity of such combination of spatial (zones) and temporal (years) gradients for more efficient differentiation and selection of the superior genotypes at the final stage of spring barley breeding process.
Fig. 5 shows the average environment coordination of the breeding lines in terms of mean yield and stability. The line intersecting the origin of the GGE biplot from left to right is the average environment abscissa (or AEA) for the environments. In the direction marked with arrow in the small circle on the abscissa, the genotypes are ranked by mean yield. The AEA intersects in the GGE biplot origin with the average ordinate. The intersection point represents the mean yield of the experiment, however, not in tons per hectare, but in the principal components values. 
The breeding line G6 had the highest yield performance, and the variety G16 had the poorest one. The breeding lines G4, G8, G3, G7, G10, G2, and G9, as well as the varieties G12, G11, G20, and G1 also exceeded the grand mean yield in trial. The breeding lines G6, G8, G2, and the varieties G12, G17, G15, G13, had the highest stability, as it was evidenced by their minimal deviation from the AEA. However, the varieties G17, G15, and G13 had yield lower than grand mean. The breeding lines G10, G5, and the variety G14 were characterized by strong variability. It should also be noted that the breeding lines G4 and G5 of the same origin, as a number of other lines in competitive testing in 2015, had equal yield. Resulted from multi-environment trials their contrast response on combination of local environments and years of testing was revealed. The data obtained demonstrate the efficiency of the trials to evaluate the lines more accurately at the final stage of breeding process. The breeding line G6 had the most optimal yield and stability combination throughout test environments. Accordingly, this breeding line was as close as possible to the "ideal" genotype, which theoretically should be located in the center of centric circles (Fig. 6). Beside the breeding line G6, according to the combination of productivity and stability, the breeding lines G4, G8, G3 should be also highlighted.

\section{CONCLUSION}

An effective method for organizing multi-environment trial in the final stage of spring barley breeding process has been proposed. It contributes to a comprehensive evaluation of the genotype by environment interaction and differentiation of genotypes in terms of yield performance and stability. As a practical result its implementation in 2015-2017, spring barley breeding lines Nutans 4941, Deficiens 5005, Nutans 4855, and Nutans 4890 with the optimal combination of superior yield performance and stability have been identified. These breeding lines as newly developed spring barley varieties MIP Myroslav, MIP Visnyk, MIP Ekspert, and MIP Vdiachnyi, respectively were submitted to the State Variety Testing of Ukraine. At present, these varieties have been included in the State Register of Ukraine for the Forest-Steppe and Polissia zones.

\section{REFERENCES}

ABTEW, W. G., LAKEW, B., HAUSSMANN, B. I. G. and SCHMID, K. J. 2015. Ethiopian barley landraces show higher yield stability and comparable yield to improved varieties in multi-environment field trials. J. Plant Breed. Crop Sci., 7(8): 275-291.

AHMADI, J., VAEZI, B. and FOTOKIAN, M. H. 2012. Graphical analysis of multi-environment trials for barley yield using AMMI and GGE-biplot under rain-fed conditions. J. Plant Physiol. Breed., 2(1): 43-54.

AL-GHZAWI, A. L. A., AL-AJLOUNI, Z. I., AL SANE, K. O., BSOUL, E. Y., MUSALLAM, I., KHALAF, Y. B., AL-HAJAJ, N., AL-TAWAHA, A. R., ALDWAIRI, Y. and AL-SAQQAR, H. 2019. Yield stability and adaptation of four spring barley (Hordeum vulgare L.) cultivars under rainfed conditions. Res. on Crops, 20(1): 10-18.

AL-SAYAYDEH, R., AL-BAWALIZE, A., AL-AJLOUNI, Z., AKASH, M. W., ABU-ELENEIN, J. and AL-ABDALLAT, A. M. 2019. Agronomic evaluation and yield performance of selected barley (Hordeum vulgare L.) landraces from Jordan. Int. J. Agron., 2019: ID9575081.

ANBESSA, Y., JUSKIW, P., GOOD, A., NYACHIRO, J. and HELM, J. 2010. Selection efficiency across environments in improvement of barley yield for moderately low nitrogen environments. Crop Sci., 50(2): 451-457.

BILGIN, O., BALKAN, A., KORKUT, Z. K. and BAŞER, İ. 2018. Multi-environmental evaluation of triticale, wheat and barley genotypes by GGE biplot analysis. J. Life Sci., 12: 13-23.

BOCIANOWSKI, J., WARZECHA, T., NOWOSAD, K. and BATHELT, R. 2019. Genotype by environment interaction using AMMI model and estimation of additive and epistasis gene effects for 1000-kernel weight in spring barley (Hordeum vulgare L.). J. Appl. Genetics, 60: 127-135.

CECCARELLI, S. 1996. Adaptation to low/high input cultivation. Euphytica, 92(1-2): 203-214.

DOĞAN, Y., KENDAL, E. and ORAL, E. 2016. Identifying of relationship between traits and grain yield in spring barley by GGE biplot analysis. Agriculture and Forestry, 62(4): 239-252.

DYULGEROVA, B. and DYULGEROV, N. 2019. Genotype by environment interaction for grain yield of barley mutant lines. Agriculture (Polnohospodárstvo), 65(2): 51-58.

FANA, G., TADESE, D., SEBSIBE, H. and VERMA, R. P. S. 2018. Multi-environment trial analysis of food barley in Ethiopia using AMMI and GGE biplot methods. J. Plant Breed. Genet., 6(3): 75-85.

FERIANI, W., REZGUI, S. and CHERIF, M. 2016. Grain yield assessment of genotype by environment interaction of Tunisian doubled-haploid barley lines. J. New Sci., Agricul. Biotechnol., 27(7): 1507-1512. 
FRUTOS, E., GALINDO, M. P. and LEIVA, V. 2014. An interactive biplot implementation in R for modeling genotype-by-environment interaction. Stoch. Environ. Res. Risk. Assess., 28: 1629-1641.

GABRIEL, K. R. 1971. The biplot graphic display of matrices with application to principal component analysis. Biometrica, 58: 453-467.

GAUCH, H. G., PIEPO, H.-P. and ANNICCHIARICO, P. 2008. Statistical Analysis of Yield Trials by AMMI and GGE: Further Consideration. Crop Sci., 48: 866-889.

GUDZENKO, V. N. 2019. Statistical and graphical (GGE biplot) evaluation of the adaptive ability and stability of winter barley breeding lines. Vavilov J. Genet. Breed., 23(1): 110-118.

HILL, J. 1975. Genotype-environment interaction - a challenge for plant breeding. J. Agric. Sci., 85(3): 477-493.

HONGYU, K., GARCIA-PENA, M., DE ARAUJO, L. B. and DOS SANTOS DIAS, C. T. 2014. Statistical analysis of yield trials by AMMI analysis of genotype x environment interaction. Biomet. let., 51(2): 89-102.

KENDAL, E. and DOĞAN, Y. 2015. Stability of a candidate and cultivars (Hordeum vulgare L.) by GGE biplot analysis of multi-environment yield trial in spring barley. Agriculture and Forestry, 61(4): 307-318.

KENDAL, E., KARAMAN, M., TEKDAL, S. and DOĞAN, S. 2019. Analysis of promising barley (Hordeum vulgare L.) lines performance by AMMI and GGE biplot in multiple traits and environment. Appl. Ecol. Env. Res., 17(2): 5219-5233.

MALOSETTI, M., RIBAUT, J.-M. and VAN EEUWIJK, F. A. 2013. The statistical analysis of multienvironment data: modeling genotype-by-environment interaction and its genetic basis. Front. Physiol., 4: Article 44.

MANIRUZZAMAN, I., ISLAM, M. Z., BEGUM, F., KHAN, M. A. A., AMIRUZZAMAN, M. and HOSSAIN, A. 2019. Evaluation of yield stability of seven barley (Hordeum vulgare L.) genotypes in multiple environments using GGE biplot and AMMI model. Open Agriculture, 4(1): 284-293.

MEHARI, M., ALAMEREW, S. and LAKEW, B. 2014. Genotype $\times$ environment interaction and yield stability of malt barley genotypes evaluated in Tigray, Ethiopia using the AMMI analysis. Asian J. Plant Sci., 13(2): 73-79.

MENG, Y., REN, P., MA, X., LI, B., BAO, Q., ZHANG, H., WANG, J., BAI, J. and WANG, H. 2016. GGE biplot-based evaluation of yield performance of barley genotypes across different environments in China. J. Agr. Sci. Tech., 18: 533-543.

MIROSAVLJEVIĆ, M., ČANAK, P., MOMČILOVIĆ, V., JOCKOVIĆ, B., ZORIĆ, M., AĆIN, V., DENČIĆ, S. and PRŽULJ, N. 2018. Identification of favorable testing location for barley breeding in South Pannonian Plain. J. Agri. Sci., 24: 303-311.

MIROSAVLJEVIĆ, M., PRŽULJ, N., BOĆANSKI, J., STANISAVLJEVIĆ, D. and MITROVIĆ, B. 2014. The application of AMMI model for barley cultivars evaluation in multi-year trials. Genetika, 46: 445-454.

MOHAMMADI, M., SHARIFI, P. and KARIMIZADEH, R. 2014. Stability analysis of durum wheat genotypes by regression parameteres in dryland conditions. Acta Univ. Agric. Silvic. Mendelianae Brun., 62(5): 1049-1056.

ORAL, E., KENDAL, E. and DOĞAN, Y. 2018. Influence of nitrogen fertilization levels on grain yield and its components in barley (Hordeum vulgare L.). Agriculture and Forestry, 64(2): 43-63.

PRŽULJ, N., MIROSAVLJEVIĆ, M., ČANAK, P., ZORIĆ, M. and BOĆANSKI, J. 2015. Evaluation of spring barley performance by biplot analysis. Cereal Res. Commun., 43(4): 692-703.

PSWARAYI, A., VAN EEUWIJK, F. A., CECCARELLI, S., GRANDO, S., COMADRAN, J., RUSSELL, J. R., PECCHIONI, N., TONDELLI, A., AKAR, T., AL-YASSIN, A., BENBELCACEM, A., OUABBOU, H., THOMAS, W. T. B. and ROMAGOSA, I. 2008. Changes in allele frequencies in landraces, old and modern barley cultivars of marker loci close to QTL for grain yield under high and low input conditions. Euphytica, 163(3): 435-447.

SABAGHNIA, N., MOHAMMADI, M. and KARIMIZADEH, R. 2013. Yield stability of performance in multi-environment trials of barley (Hordeum vulgare L.) genotypes. Acta Univ. Agric. Silvic. Mendelianae Brun., 61(3): 787-793.

SOLONECHNYI, P., KOZACHENKO, M., VASKO, N., GUDZENKO, V., ISHENKO, V., KOZELETS, G., USOVA, N., LOGVINENKO, Y. and VINUKOV, A. 2018. AMMI and GGE biplot analysis of yield performance of spring barley (Hordeum vulgare L.) varieties in multi environment trials. Agriculture and Forestry, 64(1): 121-132.

SOLONECHNYI, P., VASKO, N., NAUMOV, A., SOLONECHNAYA, O., VAZHENINA, O., BONDAREVA, O. and LOGVINENKO, Y. 2015. GGE biplot analysis of genotype by environment interaction of spring barley varieties. Zemdirbyste-Agriculture, 102(4): 431-436.

TAHERIPOURFARD, Z., IZADI-DARBANDI, A., GHAZVINI, H., EBRAHIMI, M., MORTAZAVIAN, S. M. M. and ABDIPOUR, M. 2017. Identifying superior barley (Hordeum vulgare L.) genotypes using GGEbiplot across warm and moderate environments under irrigated conditions in Iran. Crop Breed. J., 7(1, 2): 23-35. 
ULLRICH, S. E. (ed.). 2011. Barley: production, improvement, and uses. Chichester, UK: WileyBlackwell, $637 \mathrm{p}$.

VAEZI, B., POUR-ABOUGHADAREH, A., MOHAMMADI, R., ARMION, M., MEHRABAN, A., HOSSEINPOUR, T. and DORII, M. 2017. GGE biplot and AMMI analysis of barley yield performance in Iran. Cereal Res. Commun., 45(3): 500-511.

VAN EEUWIJK, F. A., BUSTOS-KORTS, D. V. and MALOSETTI, M. 2016. What should students in plant breeding know about the statistical aspects of genotype $\times$ environment interactions? Crop Sci., 56(5): 2119-2140.

VAN OOSTEROM, E. J. and ACEVEDO, E. 1992. Adaptation of barley (Hordeum vulgare L.) to harsh Mediterranean environments III. Plant ideotype and grain yield. Euphytica, 62(1): 29-38.

VASYLKIVSKYI, S. and GUDZENKO, V. 2017. Winter barley selection in steady grain production provision in the Central Forest-steppe of Ukraine. Agrobiology, 1: 25-33.

VERMA, A., KUMAR, V., KHARAB, A. S. and SINGH, G. P. 2019. AMMI model to estimate G×E for grain yield of dual purpose barley genotypes. Int. J. Curr. Microbiol. App. Sci., 8(5): 1-7.

VON KORFF, M., GRANDO, S., DEL GRECO, A., THIS, D., BAUM, M. and CECCARELLI, S. 2008. Quantitative trait loci associated with adaptation to Mediterranean dryland conditions in barley. Theor. Appl. Genet., 117(5): 653-669.

YAN, W., KANG, M. S., MA, B., WOODS, S. and CORNELIUS, P. L. 2007. GGE biplot vs. AMMI analysis of genotype-by-environment data. Crop Sci., 47: 641-653.

YAN, W. and TINKER, N. A. 2006. Biplot analysis of multi-environment trial data: principles and applications. Can. J. Plant Sci., 86: 623-645.

YAN, W. 2018. LG biplot: a graphical method for mega-environment investigation using existing crop variety trial data. Sci. Rep., 9: 7130.

ZHAO, F. and XU, S. 2012. Genotype by environment interaction of quantitative traits: a case study in barley. G3. Genes. Genomes. Genetics, 2(7): 779-788.

Contact information

Volodymyr Hudzenko: barley22@ukr.net, barley0482@gmail.com

Tetiana Polishchuk: polistchuk.tetiana@gmail.com

Oleksand Demydov: a.demydov@meta.ua

Mykola Sardak: sds11@ukr.net

Nataliia Buniak: sds11@ukr.net

Vitalii Ishchenko: semena2013@ukr.net 